\title{
ПРОГНОЗУВАННЯ ПЕРЕБІГУ ХІРУРГІЧНОГО ЛІКУВАННЯ ДИФУЗНОГО ПЕРИТОНІТУ 3 УРАХУВАННЯМ КІЛЬКІСНОЇ ОЦІНКИ ФАКТОРІВ РИЗИКУ
}

\author{
Івано-Франківський національний медичний університет
}

Досліджена можливість кількісної оцінки факторів ризику виникнення ускладнень при лікуванні дифузного перитоніту. Виділено 53 групи ознак, що мають значення при прогнозуванні перебігу дифузного перитоніту. Пропонована схема визначення ризику клінічного перебігу дифузного перитоніту дозволяє кількісно оцінити важкість вихідного стану хворих й у більшості випадків правильно спрогнозувати результати лікування захворювання.

Ключові слова: перитоніт, фактори ризику, прогнозування ускладнень.

\section{ПРОГНОЗИРОВАНИЕ ТЕЧЕНИЯ ХИРУРГИЧЕСКОГО ЛЕЧЕНИЯ ДИФФУЗНОГО ПЕРИТОНИТА НА ОСНОВАНИИ КОЛИЧЕСТВЕННОЙ ОЦЕНКИ ФАКТОРОВ РИСКА}

\author{
И. К. Чурпий \\ Ивано-Франковский национальный медицинский университет
}

\begin{abstract}
Исследована возможность количественной оценки факторов риска возникновения осложнений при лечении диффузного перитонита. Выделено 53 группы признаков, имеющих значение при прогнозировании течения диффузного перитонита. Предлагаемая схема определения риска клинического течения диффузного перитонита позволяет количественно оценить тяжесть исходного состояния больных и в большинстве случаев правильно спрогнозировать результаты лечения заболевания.
\end{abstract}

Ключевые слова: перитонит, факторы риска, прогнозирование осложнений.

\section{PREDICTION OF SURGICAL TREATMENT WITH POUR PERITONITIS QUANTIFYING RISK FACTORS}

\section{K. Churpiy}

\section{Ivano-Frankivsk State Medical University}

\begin{abstract}
it was studied the possibility of quantitative assessment of risk factors of complications in the treatment of diffuse peritonitis. There were determined 53 groups of features that are important in predicting the course of diffuse peritonitis. The proposed scheme of defining the risk of clinical course of diffuse peritonitis can quantify the severity of the source of patients and in most cases correctly predict the results of treatment of the disease.
\end{abstract}

Key words: peritonitis, factors risk, prognosis complication.

Вступ. Застосування інформаційних технологій i математичних методів дозволяє істотно підвищити якість, раціональність медичної діагностики і лікувального процесу. Аналітичні способи вирішення діагностичних завдань і планування лікувальних заходів дозволяють оптимізувати процес лікування хворих на перитоніт [1, 2, 3, 4].

Метою нашого дослідження було визначення прогностичної значимості найважливіших клінічних ознак як факторів ризику для прогнозування перебігу та результату лікування дифузного перитоніту. (c) I. К. Чурпій
Матеріал і методи. Здійснений ретроспективний аналіз 200 медичних карт стаціонарних хворих з дифузним перитонітом різної етіології. Всі обстеження проводилися при надходженні в клініку (до початку лікування) та після інтраопераційної санації черевної порожнини.

Структура патології була наступною: гострий гангренозний апендицит (ГГА) - 18, гострий перфоративний апендицит (ГПА) - 32, гострий калькульозний холецистит (ГКХ) - 36, перфоративна виразка шлунка та ДПК - 8, гостра кишкова непрохідність - 8, защемлена грижа - 19, апоплексія - 45, сальпінгіт - 
19, гострий тромбоз мезентеріальних судин - 1, травми органів черевної порожнини - 1, перфорація - 5, рак - 3, хвороба Крона - 5 випадків.

Із 200 хворих з дифузним перитонітом після хірургічного лікування померло 5. Ці пацієнти мали високий ризик летального наслідку і це підтверджує високу прогностичну цінність кількісної оцінки факторів ризику.

Всім хворим здійснювали загальноклінічне обстеження: збір скарг, анамнезу хвороби, фізикальне обстеження, клініко-лабораторні обстеження та їх інтегральна оцінка.

Вивчення передопераційного, інтра- та післяопераційного стану хворих стало основою прогнозування перебігу захворювання і становить базу "факторів ризику". Їх визначали шляхом оцінки значення клінічних показників в визначенні ймовірності виникнення ускладнень під час лікування хворих.
Відповідно, на першому етапі дослідження була створена карта автоматизованого обліку хворого з перитонітом, яка включала дані клініко-лабораторних обстежень, відомості анамнезу і операційні знахідки.

Кількісні значення прогностичної значимості клінічної інформації здійснювали з використанням методики М. М. Амосова та співавторів [5].

Всього аналізували 166 ознак перитоніту, що включали дані анамнезу, клінічного обстеження, лабораторних, спеціальних та інструментальних методів.

Результати дослідження та обговорення отриманих матеріалів.

На підставі дослідження й аналізу 22 груп клінічних ознак та їх градацій (шаблонів), що вивчалися для виявлення факторів ризику перебігу перитоніту (табл.1) було відібрано 53 найбільш значимих фак-

Таблиця 1. Групи клінічних ознак та їх градації (шаблони), що вивчалися для виявлення факторів ризику перебігу перитоніту

\begin{tabular}{|c|c|c|c|c|c|c|}
\hline \multirow{3}{*}{$\begin{array}{l}\text { № } \\
\Pi / \Pi\end{array}$} & \multirow{3}{*}{ Фактор } & \multirow{3}{*}{$\begin{array}{c}\text { Кількість } \\
\text { спостережень }\end{array}$} & \multicolumn{3}{|c|}{ Результат } & \multirow{3}{*}{$\begin{array}{c}\text { Значення, } \\
\text { бали }\end{array}$} \\
\hline & & & \multirow{2}{*}{$\begin{array}{c}\text { добрий } \\
\text { осіб }\end{array}$} & \multicolumn{2}{|c|}{ несприятливий } & \\
\hline & & & & осіб & $\%$ & \\
\hline 1. & Чоловіча стать & 67 & 65 & 1 & 1,49 & $-0,3$ \\
\hline 2. & Жіноча стать & 133 & 130 & 4 & 3,0 & $-0,15$ \\
\hline 3. & $\begin{array}{l}\text { Вік: } \\
18-20 \\
21-30 \\
31-40 \\
41-50 \\
51-60 \\
61-75 \\
76-90 \\
>90 \\
\end{array}$ & $\begin{array}{c}21 \\
37 \\
33 \\
38 \\
35 \\
24 \\
11 \\
1\end{array}$ & $\begin{array}{c}21 \\
37 \\
33 \\
38 \\
35 \\
22 \\
9 \\
0 \\
\end{array}$ & $\begin{array}{l}0 \\
0 \\
0 \\
0 \\
0 \\
2 \\
2 \\
1\end{array}$ & $\begin{array}{c}0 \\
0 \\
0 \\
0 \\
0 \\
8,3 \\
18,2 \\
100\end{array}$ & $\begin{array}{c}0 \\
0 \\
0 \\
0 \\
0 \\
1,70 \\
4,6 \\
28,7\end{array}$ \\
\hline 4. & $\begin{array}{l}\text { Поширеність перитоніту: } \\
\text { Дифузний }\end{array}$ & 200 & 195 & 5 & 3,5 & 0 \\
\hline 5. & $\begin{array}{l}\text { Термін госпіталізації: } \\
\text { До } 6 \text { год } \\
\text { 6-12 год } \\
\text { 12-24 год } \\
\text { 24-48 год } \\
48-72 \text { год } \\
>72 \text { год }\end{array}$ & $\begin{array}{c}9 \\
66 \\
68 \\
29 \\
20 \\
8\end{array}$ & $\begin{array}{c}9 \\
66 \\
67 \\
27 \\
19 \\
7\end{array}$ & $\begin{array}{l}0 \\
0 \\
1 \\
2 \\
1 \\
1\end{array}$ & $\begin{array}{c}0 \\
0 \\
1,5 \\
6,9 \\
5 \\
12,5\end{array}$ & $\begin{array}{c}0 \\
0 \\
-0,3 \\
1,3 \\
0,73 \\
2,9 \\
\end{array}$ \\
\hline 6. & $\begin{array}{l}\text { Місцевість проживання: } \\
\text { Місто } \\
\text { Село } \\
\end{array}$ & $\begin{array}{l}138 \\
62 \\
\end{array}$ & $\begin{array}{c}137 \\
58\end{array}$ & $\begin{array}{l}1 \\
4\end{array}$ & $\begin{array}{c}0,72 \\
6,4\end{array}$ & $\begin{array}{c}-0,52 \\
1,15 \\
\end{array}$ \\
\hline 7. & $\begin{array}{l}\text { Перенесені захворювання, шкідливі } \\
\text { звички: } \\
\text { Інсульт } \\
\text { Інфаркт міокарда } \\
\text { Гепатит } \\
\text { Перенесені операції на ОЧП } \\
\text { Травми ОЧП } \\
\text { Алергічні захворювання } \\
\text { Вживання алкоголю } \\
\text { Куріння }\end{array}$ & $\begin{array}{c}13 \\
19 \\
23 \\
23 \\
19 \\
12 \\
7 \\
27 \\
\end{array}$ & $\begin{array}{c}11 \\
15 \\
21 \\
22 \\
18 \\
11 \\
7 \\
26 \\
\end{array}$ & $\begin{array}{l}2 \\
4 \\
2 \\
1 \\
1 \\
1 \\
0 \\
1 \\
\end{array}$ & $\begin{array}{c}15,4 \\
21,0 \\
8,7 \\
4,3 \\
5,3 \\
8,3 \\
0 \\
3,7 \\
\end{array}$ & $\begin{array}{c}3,8 \\
5,4 \\
1,82 \\
0,53 \\
0,8 \\
1,70 \\
0 \\
0,35 \\
\end{array}$ \\
\hline
\end{tabular}


Продовження табл. 1

\begin{tabular}{|c|c|c|c|c|c|c|}
\hline \multirow{3}{*}{$\begin{array}{l}\text { № } \\
\text { п/п }\end{array}$} & \multirow{3}{*}{ Фактор } & \multirow{3}{*}{$\begin{array}{c}\text { Кількість } \\
\text { спостережень }\end{array}$} & \multicolumn{3}{|c|}{ Результат } & \multirow{3}{*}{$\begin{array}{c}\text { Значення, } \\
\text { бали }\end{array}$} \\
\hline & & & \multirow{2}{*}{$\begin{array}{c}\text { добрий } \\
\text { осіб }\end{array}$} & \multicolumn{2}{|c|}{ несприятливий } & \\
\hline & & & & осіб & $\%$ & \\
\hline \multirow[t]{14}{*}{8.} & Етіологічний чинник: & & & & & \\
\hline & Гострий гангренозний апендицит & 18 & 18 & 0 & 0 & 0 \\
\hline & Гострий перфоративний апендицит & 32 & 32 & 0 & 0 & 0 \\
\hline & Гострий калькульозний холецистит & 36 & 36 & 0 & 0 & 0 \\
\hline & Защемлена грижа & 19 & 17 & 2 & 10,5 & 2,35 \\
\hline & Апоплексія яєчників & 45 & 45 & 0 & 0 & 0 \\
\hline & Сальпінгіт & 19 & 19 & 0 & 0 & 0 \\
\hline & Гостра кишкова непрохідність & 8 & 8 & 0 & 0 & 0 \\
\hline & Перфоративна виразка ДПК & 8 & 8 & 0 & 0 & 0 \\
\hline & Гострий тромбоз мезентеріальних судин & 1 & 1 & 0 & 0 & 0 \\
\hline & Травми ОЧП & 1 & 1 & 0 & 0 & 0 \\
\hline & Перфорація кишки & 5 & 4 & 1 & 20 & 5,15 \\
\hline & Рак & 3 & 1 & 2 & 66,7 & 18,9 \\
\hline & Хвороба Крона & 5 & 5 & 0 & 0 & 0 \\
\hline \multirow[t]{8}{*}{9.} & Характер ексудату: & & & & & \\
\hline & Серозний & 17 & 17 & 0 & 0 & 0 \\
\hline & Серозно-фібринозний & 65 & 65 & 0 & 0 & 0 \\
\hline & Гнійний & 18 & 18 & 0 & 0 & 0 \\
\hline & Гнійно-фібринозний & 37 & 36 & 1 & 2,7 & 0,06 \\
\hline & Жовчний & 8 & 8 & 0 & 0 & 0 \\
\hline & Геморагічний & 46 & 46 & 0 & 0 & 0 \\
\hline & Каловий & 9 & 5 & 4 & 44,4 & 12,3 \\
\hline \multirow[t]{17}{*}{10.} & Супутня патологія: & & & & & \\
\hline & IXC, кардіосклероз & 68 & 63 & 5 & 7,3 & 1,4 \\
\hline & Порушення серцевого ритму & 16 & 12 & 4 & 25 & 6,6 \\
\hline & Гіпертонічна хвороба II-III ст. & 67 & 62 & 5 & 7,5 & 1,5 \\
\hline & Цукровий діабет I тип & 6 & 6 & 0 & 0 & 0 \\
\hline & Цукровий діабет II тип & 11 & 8 & 3 & 27,3 & 7,3 \\
\hline & Ожиріння II-IV ст. & 44 & 43 & 1 & 2,3 & $-0,06$ \\
\hline & Анемія & 9 & 7 & 2 & 22,2 & 5,8 \\
\hline & Захворювання бронхів та легень & 30 & 29 & 1 & 3,3 & 0,23 \\
\hline & Захворювання печінки & 30 & 27 & 3 & 10 & 2,2 \\
\hline & Захворювання нирок & 11 & 10 & 1 & 9,1 & 1,9 \\
\hline & Ревматична хвороба серця & 17 & 16 & 1 & 5,9 & 1,0 \\
\hline & СНІД & 2 & 2 & 0 & 0 & 0 \\
\hline & Спайкова хвороба очеревини & 26 & 22 & 4 & 15,4 & 3,8 \\
\hline & Варикозна хвороба нижніх кінцівок & 71 & 66 & 5 & 7,0 & 1,32 \\
\hline & Захворювання підшлункової залози & 17 & 15 & 2 & 11,8 & 2,7 \\
\hline & Виразкова х-ба шлунка і ДПК & 13 & 11 & 2 & 15,4 & 3,8 \\
\hline \multirow[t]{4}{*}{11.} & Пульс: (уд/хв.) < 70 & 2 & 2 & 0 & 0 & 0 \\
\hline & $70-90$ & 17 & 17 & 0 & 0 & 0 \\
\hline & $90-110$ & 118 & 117 & 1 & 0,85 & $-0,48$ \\
\hline & $>110$ & 63 & 59 & 4 & 6,3 & 1,1 \\
\hline \multirow[t]{4}{*}{12.} & Фази розвитку перитоніту: & & & & & \\
\hline & Реактивна & 102 & 102 & 0 & 0 & 0 \\
\hline & Токсична & 93 & 93 & 0 & 0 & 0 \\
\hline & Термінальна & 5 & 0 & 5 & 100 & 28,7 \\
\hline \multirow[t]{5}{*}{13.} & $\begin{array}{l}\text { Об'єм оперативних втручань: } \\
\text { Апендектомія }\end{array}$ & 50 & 50 & 0 & 0 & 0 \\
\hline & Висічення виразки з пілоропластикою & 8 & 8 & 0 & 0 & 0 \\
\hline & Ліквідація непрохідності & 8 & 8 & 0 & 0 & 0 \\
\hline & Операція Гартмана & 2 & 1 & 1 & 50 & 14,0 \\
\hline & Ушивання рани печінки & 1 & 1 & 0 & 0 & 0 \\
\hline
\end{tabular}


Продовження табл. 1

\begin{tabular}{|c|c|c|c|c|c|c|}
\hline \multirow{3}{*}{$\begin{array}{l}\text { № } \\
\Pi / \Pi\end{array}$} & \multirow{3}{*}{ Фактор } & \multirow{3}{*}{$\begin{array}{c}\text { Кількість } \\
\text { спостережень }\end{array}$} & \multicolumn{3}{|c|}{ Результат } & \multirow{3}{*}{$\begin{array}{c}\text { Значення, } \\
\text { бали }\end{array}$} \\
\hline & & & \multirow{2}{*}{$\begin{array}{c}\text { добрий } \\
\text { осіб }\end{array}$} & \multicolumn{2}{|c|}{ несприятливий } & \\
\hline & & & & осіб & $\%$ & \\
\hline \multirow[t]{10}{*}{13.} & Спленектомія & 1 & 1 & 0 & 0 & 0 \\
\hline & Грижовисікання & 17 & 17 & 0 & 0 & 0 \\
\hline & Грижовисікання+резекція кишечника & 2 & 0 & 2 & 100 & 28,7 \\
\hline & Холецистектомія (відкрита) & 3 & 3 & & 0 & 0 \\
\hline & Лапароскопічна холецистектомія & 33 & 33 & 0 & 0 & 0 \\
\hline & Клиноподібна резекція яєчника & 19 & 19 & 0 & 0 & 0 \\
\hline & Діагностична лапароскопія & 46 & 46 & 0 & 0 & 0 \\
\hline & Ушивання рани кишечника & 5 & 4 & 1 & 20 & 5,1 \\
\hline & Накладання обхідного анастомозу & 2 & 2 & 0 & 0 & 0 \\
\hline & Не оперований & 0 & 0 & 0 & 0 & 0 \\
\hline \multirow[t]{6}{*}{14.} & Тривалість операції: (хв) & & & & & \\
\hline & До 60 & 44 & 44 & 0 & 0 & 0 \\
\hline & $60-90$ & 83 & 83 & 0 & 0 & 0 \\
\hline & $90-120$ & 47 & 47 & 0 & 0 & 0 \\
\hline & $120-180$ & 22 & 18 & 4 & 18,2 & 4,6 \\
\hline & $>180$ & 4 & 3 & 1 & 25 & 6,6 \\
\hline \multirow[t]{3}{*}{15.} & Розчини для санації черевної & & & & & \\
\hline & $\begin{array}{l}\text { Порожнини: } \\
\text { Фурацилін }\end{array}$ & 124 & 119 & 5 & 4.03 & 0.43 \\
\hline & Декасан & 76 & 76 & 0 & 0 & 0 \\
\hline \multirow[t]{5}{*}{16.} & Розміщення гумово-трубчастого & & & & & \\
\hline & дренажу при дренуванні: & 43 & 43 & 0 & 0 & 0 \\
\hline & $\begin{array}{l}\text { через рану } \\
\text { Класичні точкии }\end{array}$ & 147 & 142 & 5 & 3.4 & 0.26 \\
\hline & Додаткове дренування & 2 & 2 & 0 & 0 & 0 \\
\hline & Дренаж типу "сигара" & 8 & 7 & 1 & 12,5 & 2,9 \\
\hline \multirow[t]{8}{*}{17.} & Ускладнення зі сторони рани: & & & & & \\
\hline & Інфільтрат & 6 & 6 & 0 & 0 & 0 \\
\hline & Серома & 9 & 9 & 0 & 0 & 0 \\
\hline & Нагноєння & 9 & 8 & 1 & 11,1 & 2,5 \\
\hline & Гематома & 8 & 8 & 0 & 0 & 0 \\
\hline & Розходження швів апоневрозу & & & & & \\
\hline & (евентерація) & 1 & 0 & 1 & 100 & 28,7 \\
\hline & Розходження країв рани (евентерація) & 3 & 2 & 1 & 33,3 & 9,06 \\
\hline \multirow[t]{14}{*}{18.} & Ускладнення після операції: & & & & & \\
\hline & Рання спайкова кишкова непрохідність & 10 & 8 & 2 & 20 & 5,14 \\
\hline & Кишкова нориця & 3 & 3 & 0 & 0 & 0 \\
\hline & Абсцеси черевної порожнини & 2 & 1 & 1 & 50 & 14 \\
\hline & Післяопераційна пневмонія & 27 & 22 & 5 & 18,5 & 4,7 \\
\hline & Плеврит & 13 & 10 & 3 & 23,1 & 6,06 \\
\hline & Перикардит & 2 & 1 & 1 & 50 & 14 \\
\hline & Інфаркт міокарда & 1 & 0 & 1 & 100 & 28,7 \\
\hline & ТЕЛА & 1 & 0 & 1 & 100 & 28,7 \\
\hline & Поліорганна недостатність & 22 & 17 & 5 & 22,7 & 6,5 \\
\hline & Тривалий парез кишечника & 53 & 48 & 5 & 9,4 & 2,03 \\
\hline & Тромбоз глибоких вен нижніх кінцівок & 2 & 2 & 0 & 0 & 0 \\
\hline & Тромбофлебіт н/к & 9 & 9 & 0 & 0 & 0 \\
\hline & Післяопераційний панкреатит & 16 & 15 & 1 & 6,25 & 1,10 \\
\hline \multirow[t]{4}{*}{19.} & Кількість проведених лапаротомій: & & & & & \\
\hline & 1 pa3 & 9 & 7 & 2 & 22,2 & 5,8 \\
\hline & 2 рази & 0 & 0 & 0 & 0 & 0 \\
\hline & $>2$ pa3 & 0 & 0 & 0 & 0 & 0 \\
\hline
\end{tabular}


Продовження табл. 1

\begin{tabular}{|c|c|c|c|c|c|c|}
\hline \multirow{3}{*}{$\begin{array}{l}\text { № } \\
\Pi / \Pi\end{array}$} & \multirow{3}{*}{ Фактор } & \multirow{3}{*}{$\begin{array}{c}\text { Кількість } \\
\text { спостережень }\end{array}$} & \multicolumn{3}{|c|}{ Результат } & \multirow{3}{*}{$\begin{array}{c}\text { Значення, } \\
\text { бали }\end{array}$} \\
\hline & & & \multirow{2}{*}{$\begin{array}{c}\text { добрий } \\
\text { осіб }\end{array}$} & \multicolumn{2}{|c|}{ несприятливий } & \\
\hline & & & & осіб & $\%$ & \\
\hline 20. & 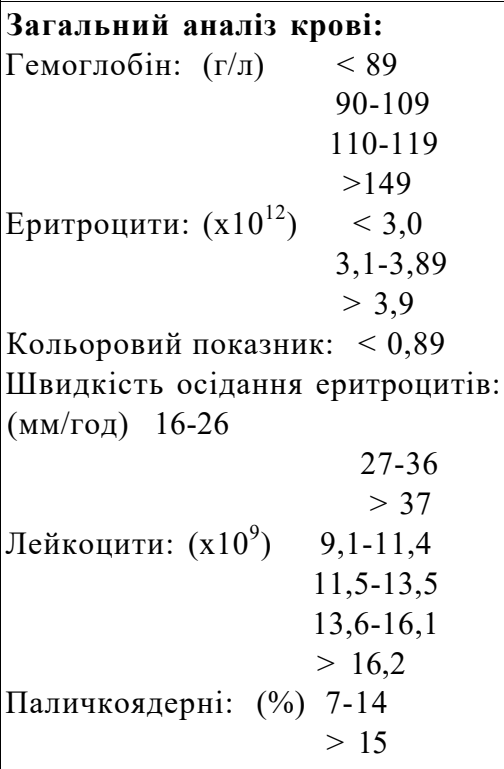 & $\begin{array}{c}6 \\
148 \\
39 \\
7 \\
15 \\
171 \\
14 \\
193 \\
\\
161 \\
28 \\
11 \\
17 \\
19 \\
106 \\
58 \\
148 \\
52\end{array}$ & $\begin{array}{c}160 \\
25 \\
11 \\
17 \\
18 \\
104 \\
56 \\
146 \\
50\end{array}$ & $\begin{array}{l}1 \\
3 \\
0 \\
0 \\
0 \\
2 \\
3 \\
2 \\
3\end{array}$ & $\begin{array}{c}0,62 \\
10,7 \\
0 \\
0 \\
0 \\
1,9 \\
5,17 \\
1,3 \\
5,8\end{array}$ & $\begin{array}{c}9,05 \\
-0,32 \\
0 \\
0 \\
5,15 \\
-0,56 \\
0 \\
0 \\
\\
-0,55 \\
2,4 \\
0 \\
0 \\
0 \\
-0,18 \\
0,78 \\
-0,35 \\
0,97\end{array}$ \\
\hline 21. & $\begin{array}{lc}\text { Біохімічний аналіз } & \text { крові: } \\
\text { АсАТ (од/л): } & <0,44 \\
& 0,45-0,90 \\
\text { АлАТ (од/л): } & <0,91 \\
& 0,50-0,90 \\
& >0,91 \\
\text { Загальний білок (г/л): } & <55 \\
& 56-65 \\
\text { Альбуміни (\%): } & <35 \\
& >55 \\
\text { Креатинін (мкмоль/л): } & <44 \\
& 115-150 \\
& >151 \\
\text { Сечовина (мкмоль/л): } & 8,4-14,31 \\
& >14,32 \\
\text { Глюкоза (ммоль/л): } & >5,5 \\
\text { Загальний білірубін } & (\text { мкмоль/л): } \\
>20,52 & <3,5 \\
\text { Калій: (ммоль/л): } & 3,5-5,0 \\
\text { Натрій (ммоль/л): } & <135 \\
& 136-145 \\
\text { Хлор (ммоль/л): } & <95 \\
& 96-110 \\
& \end{array}$ & $\begin{array}{c}167 \\
26 \\
7 \\
164 \\
27 \\
9 \\
28 \\
172 \\
11 \\
189 \\
159 \\
27 \\
14 \\
\\
186 \\
14 \\
19 \\
\\
200 \\
17 \\
183 \\
11 \\
189 \\
12 \\
188 \\
\end{array}$ & $\begin{array}{c}166 \\
24 \\
5 \\
164 \\
24 \\
6 \\
23 \\
0 \\
10 \\
188 \\
0 \\
0 \\
9 \\
0 \\
0 \\
9 \\
16 \\
0 \\
196 \\
12 \\
0 \\
6 \\
0 \\
0\end{array}$ & $\begin{array}{l}1 \\
2 \\
2 \\
0 \\
2 \\
3 \\
5 \\
0 \\
4 \\
1 \\
0 \\
0 \\
5\end{array}$ & $\begin{array}{c}0,60 \\
7,7 \\
28,6 \\
0 \\
7,4 \\
33,3 \\
17,8 \\
0 \\
36,4 \\
0,53 \\
0 \\
0 \\
35,7 \\
\\
0 \\
35,7 \\
15,8\end{array}$ & $\begin{array}{c}-0,55 \\
1,5 \\
3,3 \\
0 \\
1,4 \\
9,06 \\
4,5 \\
0 \\
10 \\
-0,56 \\
0 \\
0 \\
9,8 \\
\\
0 \\
9,8 \\
3,9 \\
\\
-0,15 \\
7,9 \\
0 \\
12,6 \\
0 \\
11,5 \\
0\end{array}$ \\
\hline 22. & 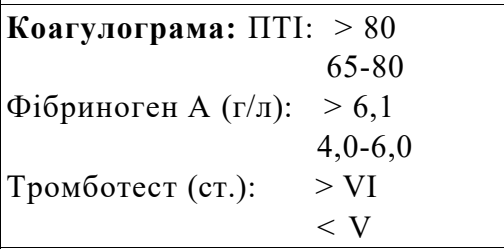 & $\begin{array}{c}14 \\
186 \\
31 \\
164 \\
38 \\
162 \\
\end{array}$ & $\begin{array}{c}14 \\
181 \\
0 \\
166 \\
38 \\
157 \\
\end{array}$ & $\begin{array}{l}0 \\
5 \\
0 \\
5 \\
0 \\
5\end{array}$ & $\begin{array}{c}0 \\
2,67 \\
0 \\
2,96 \\
0 \\
3,1 \\
\end{array}$ & $\begin{array}{c}0 \\
0,05 \\
0 \\
0,13 \\
0 \\
0,18 \\
\end{array}$ \\
\hline
\end{tabular}

Примітка: Середня частота несприятливих результатів в усіх випадках складала 2,5 \%. 
тори для прогнозування результату захворювання (табл. 2). Фактори представлені з позитивними та негативними значеннями, тобто вони можуть мати позитивне і негативне значення для прогнозу. В дос-

Таблиця 2. Прогностична значимість факторів, що визначають ускладнення перебігу дифузного перитоніту.

\begin{tabular}{|c|c|}
\hline Фактори ризику погіршення при дифузному перитоніті & Бали \\
\hline Жіноча стать & 0,15 \\
\hline Вік $61-75$ років & 1,70 \\
\hline $76-90$ років & 4,6 \\
\hline$>90$ років & 28,7 \\
\hline Госпіталізація до 48 години & 1,3 \\
\hline$>72$ годин & 2,9 \\
\hline Проживання в селі & 1,15 \\
\hline Перенесені захворювання: інсульт & 3,8 \\
\hline Інфаркт міокарда & 5,4 \\
\hline Гепатит & 1,82 \\
\hline Алергія & 1,70 \\
\hline Защемлена грижа & 2,35 \\
\hline Рак & 18,9 \\
\hline Перфорація кишки & 5,15 \\
\hline Характер ексудату: каловий & 12,3 \\
\hline Супутня патологія: порушення серцевого ритму & 6,6 \\
\hline Гіпертонічна хвороба II-III ст. & 1,5 \\
\hline Цукровий діабет II тип & 7,3 \\
\hline Анемія & 5,8 \\
\hline Захворювання печінки & 2,2 \\
\hline Захворювання нирок & 1,9 \\
\hline Варикозна хвороба нижніх кінцівок & 3,8 \\
\hline Пульс $>110$ уд/хв & 1,1 \\
\hline Термінальна фаза перитоніту & 28,7 \\
\hline Операція Гартмана & 14 \\
\hline Ушивання рани кишечника & 5,1 \\
\hline Грижовисікання з резекцією кишечника & 28,7 \\
\hline Тривалість операції: $120-180$ хв & 4,6 \\
\hline Тривалість операції: >180 хв & 6,6 \\
\hline Використання р-ну фурациліну для санації черевної порожнини & 0,43 \\
\hline Використання дренажів типу "сигара" & 2,9 \\
\hline Евентерація (повна) & 9,06 \\
\hline Нагноєння & 2,5 \\
\hline Рання кишкова непрохідність & 5,14 \\
\hline Поліорганна недостатність & 6,5 \\
\hline Післяопераційна пневмонія & 4,7 \\
\hline Абсцеси черевної порожнини & 14 \\
\hline Інфаркт міокарда & 28,7 \\
\hline Перикардит & 14 \\
\hline ТЕЛА & 28,7 \\
\hline К-ть проведених релапаротомій: 1 раз & 5,8 \\
\hline Гемоглобін: $\quad<89$ (г/л) & 9,05 \\
\hline Еритроцити: $\left(\mathrm{x} 10^{12}\right) \quad<3,0$ & 5,15 \\
\hline Швидкість осідання еритроцитів: (мм/год) 27-36 & 2,4 \\
\hline Загальний білок: (г/л) < 55 & 4,5 \\
\hline Альбуміни: $(\%) \quad<35$ & 10 \\
\hline Сечовина (кмоль/л) > 14,32 & 9,8 \\
\hline Креатинін: (мкмоль/л) >151 & 9,8 \\
\hline Натрій (ммоль/л) < 135 & 12,6 \\
\hline $\operatorname{AcAT~}($ од/л) $>0,91$ & 3,3 \\
\hline АлАТ (од/л) > 0,91 & 9,06 \\
\hline
\end{tabular}


лідженні припускається, що прогноз буде визначатися сумою балів, що характеризують важливість симптомів, виявлених у хворих. Первісне число прогностичних ознак було більшим, однак перевірка кореляційних зв'язків дозволила скоротити їхню кількість за рахунок виключення менш значимих.

При аналізі факторів, що погіршують перебіг дифузного перитоніту, найбільш вагомими визнано жіночу стать та вік. У пацієнтів старше 60 років ризик негативного перебігу перитоніту зростає прямо пропорційно зі збільшенням віку. Так у віці 61 - 75 років показник склав 1,70 бала, а у 76 - 90 років - 4,6 бала, тобто показник збільшився в 2,7 раза. У віці 90 років і більше різко зростає ймовірність погіршення прогнозу, тому прогностичне значення цього показника сягає 28,7 бала, що відповідає 100 \% летальному наслідку. Важливу роль відіграє час до госпіталізації у стаціонар. Так, якщо він не перебільшує 48 годин, то фактор ризику складає 1,3 бала. Подовження терміну госпіталізації більше 72 годин збільшує в 2 рази негативний вплив на перебіг захворювання і складає 2,9 бала. 3 даним показником опосередковано пов'язаний такий фактор ризику, як проживання в селі, він складає 1,15 бала, оскільки віддаленість від лікувального закладу та відсутність повної кваліфікованої допомоги сприяє пізній госпіталізації.

Окремою групою серед факторів високого ризику слід розглядати перенесені в анамнезі соматичні захворювання. На першому місці стоїть інфаркт міокарда - 5,4 бала, інсульт - 3,8, та гепатити - 1,82 бала, алергічні прояви - 1,70 бала.

Супутня патологія також погіршує перебіг дифузного перитоніту. Досить високим фактором ризику є порушення серцевого ритму, цукровий діабет, що складає 6,6 та 7,3 бала відповідно. В однаковій мірі впливають спайкова хвороба очеревини та виразкова хвороба шлунка та ДПК, які мають по 3,8 бала. Важливу роль відіграють анемія - 5,8 бала, захворювання підшлункової залози - 2,7, печінки - 2,2 бала, захворювання нирок - 1,9, гіпертонічна хвороба IIIII ст. - 1,5, варикозна хвороба н/кінцівок - 1,32 бала відповідно.

Серед хірургічних захворювань найбільш вагомими факторами ризику є рак, який становить - 18,9 бала, перфорація товстої кишки - 5,15 та защемлена грижа - 2,35.

При порівнянні характеру ексудату найвищий фактор ризику має каловий - 12,3 бала та гнійно-фібринозний ексудат - 0,06 бала відповідно.

При об'єктивному обстеженні пацієнта високими факторами ризику є тахікардія > 110 уд/хв, (1,1), що характеризує наявність шоку. Термінальна фаза перитоніту є найтяжчою в перебігу та прогнозуванні несприятливого наслідку (відповідне значення ї критерію дорівнює 28,7).

Найбільш травматичними оперативними втручаннями виявилися операції грижовисікання з резекцією тонкого кишечника - 28,7 бала, операція Гартмана 14,0 бала. Ушивання кишечника не належить до складних операцій, але становить 5,1 бала і займає особливе місце, оскільки проводиться при ракових пухлинах кишечника різної локалізації і тому дає високу летальність, що є прогностично несприятливим.

Оптимальна тривалість оперативного втручання повинна становити до 120 хвилин. Якщо тривалість операції від 120 - 180 хвилин, то фактор ризику складає 4,6 бала, а при тривалості > 180 хвилин - 6,6, оскільки погіршується післяопераційний перебіг та підвищується ризик летального наслідку.

Важливе значення під час операції мають вибір розчину для санації черевної порожнини та вид дренування. Зокрема, нами встановлено, що використання розчину фурациліну не дає високого терапевтичного ефекту і сприяє раннім післяопераційним ускладненням (ї-критерій 0,43), що підтверджено мікробіологічними дослідженнями. Високий фактор ризику при використанні дренажів типу "сигара" 2,9 бала.

При аналізі післяопераційних ускладнень було виділено дві групи: соматичні та ускладнення зі сторони живота та рани.

Найбільш високий летальний ризик мали ТЕЛА та інфаркт міокарда - 28,7 бала, перикардит - 14, післяопераційна пневмонія - 4,7 бала та плеврит - 2,43. Ускладненнями зі сторони живота, що мали найбільш несприятливий вплив на перебіг захворювання, були абсцеси черевної порожнини - 14 та рання кишкова непрохідність - 5,14. Зі сторони рани - евентерація 9,06 бала, нагноєння - 2,5.

Кількість проведених релапаротомій при дифузному перитоніті також має прогностично несприятливий наслідок для життя пацієнта. Нами встановлено, що при одноразовій релапаротомії і- критерій дорівнює 5,8 .

Характерним відображенням перебігу перитоніту $\epsilon$ динаміка лабораторних показників. Найбільш прогностично цінними є рівень гемоглобіну - 9,05, кількість еритроцитів - 5,15, кількість лейкоцитів > $16,2 \times 10^{9}$ склала 0,78 бала, показник паличкоядерних нейтрофілів > 15\% - 0,97 бали. Високу прогностичну цінність мають такі біохімічні показники як загальний білок - 4,5, альбуміни < 35\% - 10 АсАТ - 3,3, 
АлАТ - 9,06 бала. Дані лабораторного аналізу характеризують інтоксикаційний синдром та тяжкість перебігу перитоніту. Більшість отриманих показників мають високу інформаційно-клінічну цінність та корелюють $з$ даними літератури й відрізняються тільки тим, що кількісно характеризують важкість захворювання.

Погіршення стану обумовлене виникненням поліорганної недостатності в післяопераційному періоді $\epsilon$ прогностично несприятливим фактором подальшого перебігу дифузного перитоніту, що складає 6,5 бала.

Таким чином, можна вважати, що виділені та сформовані фактори ризику, наведені в цій роботі, будуть сприяти правильному ухваленню рішення при виборі обсягу консервативного та оперативного лікування даної категорії хворих.

Висновки. 1. Важливими факторами в оцінці ризику перебігу та результатів хірургічного лікування

\section{Література.}

1. Оптимізація програми комплексного лікування хворих 3 розповсюдженим гнійним перитонітом / А. І. Годлевський, В. А. Кацал, С. І. Саволюк, Н. А. Годлевська // Матеріали XXI з'їзду хірургів України. - Запоріжжя, 2005. - Т 2. С. $453-454$.

2. Прогнозирование исхода перитонита с использованием интегральных гематологических показателей / В. А. Сипливый, Е. В. Конь, Л. В. Евтушенко [и др.] // Харьківська хірургічна школа. - 2009. - № 2 (2). - С. 188 - 189.

3. Гусев А. В., Обзор медицинских информационных сис- дифузного перитоніту є жіноча стать, вік 60 - 90 років, (вік більше 90 років характеризується 100\% летальністю), час до госпіталізації більше 48 годин, проживання в сільській місцевості, наявність в анамнезі інфаркту міокарда, інсульту, порушення серцевого ритму, калового та гнійно-фібринозного ексудату, термінальної фази перебігу, операцій з резекцією кишечника та таких післяопераційних ускладнень як ТЕЛА, інфаркт міокарда, плеврит, післяопераційна пневмонія. У прогнозуванні результату комплексного лікування перитоніту варто також враховувати біохімічні показники.

2. На основі проведеного аналізу факторів ризику пропонується створити схему визначення ризику клінічного перебігу дифузного перитоніту, яка дозволить кількісно оцінити тяжкість вихідного стану хворих й у більшості випадків правильно спрогнозувати результати лікування.

тем на отечественном рынке в 2005 году / А. В. Гусев, Ф. А. Романов, И. П. Дуданов // Медицинский академический журнал. - 2005. - Т. 5, № 3. - С. 72 - 84.

4. Інформаційні технології в хірургії / О. П. Мінцер, В. 3. Москаленко, С. В. Веселий. - в 10 книгах. Кн. 3 - " Інформаційні технології в охороні здоров'я і практичній медицині". - К. : Вища школа, 2004. - 423 с.

5. Амосов Н. М. Факторы риска протезирования митрального клапана / Н. М. Амосов, Л. Н. Сидоренко, О. П. Минцер // Грудная хирургия. - 1975. - № 3. - С. 9-16. 